\title{
Peran Perempuan Pengrajin Besek Ikan Dalam Meningkatakan Ekonomi Keluarga Di Desa Sumbersewu Kecamatan Muncar Kabupaten Banyuwangi
}

\section{The Role of Women Fish Besek Craftsmen in Improving the Family Economy in Sumbersewu Village, Muncar District, Banyuwangi Regency}

\author{
Asfarina Hidayah ${ }^{1}$ \\ ${ }^{1}$ Program Studi Teknik Industri, Fakultas Teknik, Universitas 17 Agustus 1945 Banyuwangi, Jalan Adi \\ sucipto no 26, Banyuwangi, Jawa Timur, Indonesia \\ Corresponding Author: asfarina@untag-banyuwangi.ac.id
}

Submited: 22 June 2021 Revised: 09 July 2021 Accepted: 22 July 2021 Publish: 31 July 2021

Abstrak

Tujuan dari penelitian ini yaitu untuk mengetahui bentuk peran perempuan pengrajin besek ikan dalam meningkatan perekonomian keluarga dan untuk mengetahui tingkat keberhasilan perempuan pengrajin besek ikan dalam meningkatkan perekonomian keluarga. Penelitian ini merupakan penelitian deskriptif kualitatif yang menekankan pada bagaimana peran dan tingkat keberhasilan perempuan pengrajin besek ikan dalam meningkatkan ekonomi keluarga di Desa Sumbersewu Kecamatan Muncar Kabupaten Banyuwangi. Teknik pengumpulan data dalam penelitian yaitu dengan wawancara, observasi dan dokumentasi. Teknik analisis data yang digunakan dalam penelitian ini yaitu pengumpulan data, reduksi data, penyajian data dan yang terakhir penarikan kesimpulan. Hasil penelitian menunjukkan peran perempuan pengrajin besek ikan dalam meningkatan perekonomian keluarga yaitu peran mencari nafkah (publik) dan peran sebagai ibu rumah tangga (domestik), sedangkan tingkat keberhasilan perempuan pengrajin besek ikan dalam meningkatkan ekonomi keluarga adalah berkisar 32\%-42\% yang rata-rata memberikan sumbangan dalam penghasilan keluarga sebesar $37 \%$. Hasil Penelitian ini menunjukkan bahwa peran perempuan pengrajin besek ikan cukup besar dalam meningkatakan ekonomi keluarga.

Kata Kunci : Besek ikan, perempuan, pengrajin,pendapatan

\section{Abstract}

The purpose of this study was to determine the role of fish besek craftsmen in improving the family economy and to determine the success rate of fish besek craftsmen in improving the family economy. This research is a qualitative descriptive study that emphasizes the role and success rate of besek fish craftsmen in improving the family economy in Sumbersewu Village, Muncar District, Banyuwangi Regency. Data collection techniques in this study were interviews, observation, and documentation. Data analysis techniques used in this research are data collection, data reduction, data presentation and finally drawing conclusions. The results showed that the role of women fish craftsmen in improving the family economy was the role of earning a living (community) and the role of housewives (domestic), while the success rate of women fish meat craftsmen in improving the family economy was around $32 \%-42 \%$ which on average its contribution to family income is $37 \%$. The results of this study indicate that the role of besek fish craftsmen is quite large in improving the family economy.

Keywords: fish basket, women, craftsmen, income

\section{PENDAHULUAN}

Pembangunan merupakan suatu upaya sistematis yang dilakukan untuk memperbaiki dan meningkatkan kesejahteraan masyarakat.

Pembangunan ekonomi dalam suatu daerah tidak saja diukur dari kenaikan 
produksi barang dan jasa, tetapi juga diukur dari perubahan dari berbagai aspek ekonomi lainnya, seperti perkembangan pendidikan, perkembangan teknologi, peningkatan dalam kesehatan, peningkatan dalam infrastruktur yang tersedia, dan peningkatan dalam pendapatan dan kemakmuran masyarakat (Ni Putu, 2017).

Menurut Moser (Erin, 2014) membagi peran perempuan kedalam tiga aras (triple roles) yaitu pertama, kerja reproduksi dimana pekerjaan ini berada dalam ranah domestik meliputi pemeliharaan rumah tangga dan anggotanya (termasuk melahirkan, pengasuhan anak, pemeliharaan kesehatan keluarga), mengerjakan pekerjaan rumah tangga (memasak, berbelanja, membersihkan rumah). Kedua, kerja reproduktif pekerjaan yang sifatnya berada di luar rumah seperti produksi barang, jasa, dan perdagangan, pekerjaan ini lebih dihargai dibandingkan kerja reproduktif, fungsi tanggung jawab dan upah laki-laki dan perempuan seringkali berbeda, perempuan seringkali dilihat dan dinilai dibandingkan laki-laki. Ketiga, kerja sosial/komunitas biasanya bersifat perayaan-perayaan dan upacara-upacara (agama, budaya), kegiatan dalm pekerjaan sosial biasanya perempuan terlibat dalam pekerjaan reproduktif yang sifatnya komunitas atau sosial seperti memasak dalam pesta atau selamatan tetangga dimana pekerjaanini tidak dibayar dan bersifat sukarela.

Ada tiga komponen utama dalam pertumbuhan ekonomi dari setiap bangsa. Ketiganya adalah: 1. Akumulasi modal, yang meliputi semua bentuk atau jenis investasi baru yang ditanamkan pada tanah, peralatan fisik, dan modal atau sumber daya manusia. Adanya pengadaan pabrik baru, mesinmesin, peralatan dan bahan baku tentulah akan meningkatkan stok modal secara fisik suatu negara. Sedangkan investasi dalam pembinaan sumber daya manusia yang berupa penyediaan pendidikan formal, program pendidikan dan pelatihan dalam kerja atau magang, kursus-kursus dan aneka pendidikan informal lainnya, termasuk pendidikan guru yang bermutu dengan kurikulum yang tepat dan relevan, pasti akan dapat meningkatkan kualitas, kepemimpinan dan produktivitas tenaga kerja. 2. Pertumbuhan penduduk, yang beberapa tahun selanjutnya akan memperbanyak jumlah angkatan kerja. 3. Kemajuan teknologi ( Michael P. Todaro ,1998). 
Kesejahteraan Masyarakat menjadi hal krusial dalam pembangunan ekonomi terutama masyarakat yang berada di pedesaan. Dari data profil penduduk Desa Sumbersewu Kecamatan Muncar Kabupaten Banyuwangi Tahun 2020 menunjukkan tingkat kesejahteraan masyarakat jumlah keluarga prasejahtera sebanyak 243 keluarga, jumlah keluarga sejahtera 1 sebanyak 185 keluarga, jumlah keluarga sejahtera 2 sebanyak 389 keluarga, jumlah keluarga sejahtera 3 sebanyak 1890, jumlah keluarga sejahtera 3 plus sebanyak 36 dengan total jumlah kepala keluarga sebesar 2752.

Masyarakat desa yang ada di wilayah sumbersewu kecamatan muncar sebagian besar bermata pencaharian sebagai petani yaitu dengan jumlah 1837 jiwa. Selain bertani salah satu keahlian yang dimiliki masyarakat desa sumbersewu yaitu sebagia pengrajin besek ikan, keahlian ini secara turun temurun dari generasi kegenerasi yang biasanya biasanya dilakukan oleh perempuan.

Dari beberapa mata pencaharian yang dimiliki masyarakat yang berada di wilayah sumbersewu, banyak keluarga yang tidak dapat mencukupi kebutuhan rumah tangganya mulai dari kebutuhan pokok sehari-hari, kebutuhan pendidikan anak dan kebutuhan lainnya.Hal itu yang membuat kaum perempuan berupaya untuk bekerja mencari tambahan penghasilan untuk keluarganya Karena penghasilan ratarata kepala keluarga yang ada di wilayah desa sumbersewu sebesar satu sampai dua juta yang dirasa belum cukup untuk memenuhi kebutuhan rumah tangganya, dan karena rata-rata mata pencaharian kepala keluarga sebagai petani dan buruh tani maka sifat pekerjaan itu hanya musiman sehingga pendapatan mereka tidak selalu ada setiap hari. Berdasarkan uraian permasalahan tersebut, penelitian ini memiliki tujuan untuk mengetahui bentuk peran perempuan pengrajin besek ikan dalam meningkatan perekonomian dan ukuran keberhasilanya.

\section{Metode Penelitian}

\section{Waktu dan lokasi penelitian}

Waktu pelaksanaan penelitian yaitu dimulai tanggal 7 sampai 20 Maret 2021. Lokasi penelitian ini berada di Desa Sumbersewu Kecamatan Muncar, Kabupaten Banyuwangi.

\section{Rancangan penelitian}


Jenis penelitian yang digunakan dalam penelitian ini yaitu penelitian kualitatif. Penelitian kualitatif adalah cara ilmiah untuk mendapatkan data yang valid dengan tujuan dapat ditemukan, dikembangkan, dan dibuktikan suatu pengetahuan tertentu sehingga nantinya dapat digunakan untuk memahami, memecahkan, dan mengantisipasi masalah yang terjadi (Sugiyono, 2016).

\section{Metode pengumpulan data}

Sumber data yang digunakan dalam penelitian ini ada dua yaitu data primer dan data sekunder. Data primer yang dikumpulkan berupa data diri pengrajin besek ikan, data jumlah pendapatan dan kebutuhan keluarga. Teknik pengumpulan data dalam penelitian ini yaitu dengan obeservasi di lapangan, wawancara dan dokumentasi. Wawancara dilakukan kepada delapan perempuan pengrajin besek ikan di Desa Sumbersewu.

\section{Analisis data}

Penelitian ini menggunakan metode analisis deskriptif. Teknik alisis data yang digunakan dalam penelitian ini yaitu aktivitas pengumpulan data, Reduksi data, penyajian data, dan penarikan kesimpulan.

\section{HASIL DAN PEMBAHASAN}

Berdasarkan hasil wawancara dan observasi yang dilakukan di lapangan, peneliti memperoleh hasil tentang menunjukkan peran perempuan pengrajin besek ikan dalam meningkatan perekonomian keluarga yang berada di desa sumbersewu kecamatan muncar kabupaten banyuwangi. Peran perempuan pengrajin besek ikan yang ada di desa sumbersewu secara garis besar dapat diklasifikasikan menjadi dua yaitu peran pencari nafkah (publik) dan peran non ekonomi (domestik).

Peran pencari nafkah (publik) yaitu perempuan pengrajin besek ikan melakukan kegiatan yang bertujuan untuk mendapatkan uang dalam upaya meningkatkan perekonomian keluarga. Peran non ekonomi (domestik) adalah peran perempuan yang hanya melakukan aktivitas domestik yaitu diwilayah rumah tangganya dalam upaya menopang pemenuhan kebutuhan keluarga seperti merawat anak, mencuci, kebersihan rumah, pendidikan anak,dll.

Peran pencari nafkah (publik) 
Beberapa perempuan yang (publik) sebagai upaya dalam berada di desa sumbersewu kecamatan peningkatan perekonomian muncar kabupaten banyuwangi ikut keluarganya. mengabil peran sebagai pencari nafkah Tabel 1. Perhitungan penghasilan keluarga perempuan pengrajin besek ikan

\begin{tabular}{llccc}
\hline No & Nama & Pendapatan & $\begin{array}{l}\text { Pendapatan } \\
\text { Keluarga }\end{array}$ & $\begin{array}{l}\text { Prosentase } \\
\text { Sumbangan }\end{array}$ \\
\hline 1 & Ibu Juminten & 720,000 & $1,740,000$ & $41 \%$ \\
2 & Ibu Nani & 612,000 & $1,462,000$ & $42 \%$ \\
3 & Ibu Khotim & 720,000 & $1,910,000$ & $38 \%$ \\
4 & Ibu Lilis & 810,000 & $2,170,000$ & $37 \%$ \\
5 & Ibu Riati & 684,000 & $2,000,000$ & $34 \%$ \\
6 & Ibu Asih & 720,000 & $1,995,000$ & $36 \%$ \\
7 & Ibu Watini & 756,000 & $2,286,000$ & $33 \%$ \\
8 & Ibu Ana & 720,000 & $2,250,000$ & $32 \%$ \\
& Rata-rata & 717,750 & $1,976,625$ & $37 \%$ \\
\hline
\end{tabular}

Sumber : Hasil wawancara dan perhitungan (2021)

Tabel 1 menunjukkan besarnya pendapatan perempuan pengrajin besek ikan yang ada di desa sumbersewu kecamatan muncar kabupaten Banyuwangi setiap bulannya, besarnya total pendapatan keluarga, dan prosentase sumbangan penghasilan

Tabel 2 Alokasi pendapatan keluarga pengrajin besek ikan perbulan

\begin{tabular}{lcccc}
\hline Nama & Pendapatan & $\begin{array}{c}\text { Pendapatan } \\
\text { Keluarga }\end{array}$ & $\begin{array}{c}\text { Kebutuhan } \\
\text { Pangan }\end{array}$ & $\begin{array}{c}\text { Kebutuhan } \\
\text { Pendidikan }\end{array}$ \\
\hline Ibu Juminten & 720,000 & $1,740,000$ & $1,250,000$ & 450,000 \\
Ibu Nani & 612,000 & $1,462,000$ & $1,140,000$ & 150,000 \\
Ibu Khotim & 720,000 & $1,910,000$ & $1,460,000$ & 300,000 \\
Ibu Lilis & 810,000 & $2,170,000$ & $1,410,000$ & 450,000 \\
Ibu Riati & 684,000 & $2,000,000$ & $1,330,000$ & 300,000 \\
Ibu Asih & 720,000 & $1,995,000$ & $1,080,000$ & 300,000 \\
Ibu Watini & 756,000 & $2,286,000$ & $1,110,000$ & 450,000 \\
Ibu Ana & 720,000 & $2,250,000$ & $1,890,000$ & 150,000 \\
\hline
\end{tabular}

Sumber : Hasil wawancara dan perhitungan (2021)

Pendapatan keluarga pengrajin besek ikan menunjukkan bahwa pendapatan keluarga mampu mencukupi kebutuhan pangan dan pendidikan (Tabel 2). Penghasilan perempuan perempuan pengrajin besek ikan terhadap pendapatan total keluarga. Prosesntase sumbangan penghasilan perempuan pengrajin besek ikan untuk keluarganya berkisar 32\%-42\% dengan rata-rata sumbangan sebesar $37 \%$. 
Perempuan pengrajin besek ikan yang berada di desa sumbersewu kecamatan muncar kabupaten banyuwangi juga berperan non ekonomi yaitu berperan sebagai ibu rumah yang bertugas untuk mengurus keperluan keluarga termasuk memasak, membersihkan rumah, mengantarkan anak sekolah, dst. Hal ini menunjukkan bahwa perempuan pengrajin besek ikan di desa sumbersewu memiliki peran ganda yaitu peran sebagai pekerja dan peran sebagai ibu rumah tangga.

Meskipun mereka bekerja tapi perempuan pengrajin besek ikan tetap menjalankan tugasnya untuk mengurus suami dan anak-anaknya. Demikian beberapa peran perempuan pengrajin besek ikan di desa sumbersewu kecamatan muncar kabupaten banyuwangi. Beberapa jenis peran diatas merupakan upaya untuk meningkatkan perekonomian keluarganya. Tidak dapat dipungkiri bahwa ketercukupan ekonomi keluarga sangat menunjang terpenuhinya pendidikan anak dan terpenuhinya kebutuhan kesehatan keluaga.

\section{KESIMPULAN}

Peran perempuan dibagi menjadi dua kelompok besar yaitu peran pencari nafkah (publik) dan peran rumah tangga (domestik). Selanjutnya, tingkat keberhasilan perempuan pengrajin besek ikan dalam meningkatkan perekonomian keluarga yaitu sumbangan ekonomi yang diberikan oleh pengrajin besek ikan bagi pendapatan keluarga perbulan rata-rata sebesar $32 \%-42 \%$.

\section{DAFTAR PUSTAKA}

Erin Alifa Dini. (2014). Peran Ganda Perempuan Pedaagang Pakaian Kaki Lima (Studi Kasus Di Pasar Kemiri Muka Depok Jawa Barat). Skripsi. Fakultas Ilmu Sosial Dan Ilmu Politik Unversitas Islam Negeri Syarif Hidayatullah

Ni Putu Ria Sasmitha. (2017). Faktor-Faktor yang Memperngaruhi Pendapatan Pengrajin pada Industri Kerajinan Bambu Di Desa Belega Kabupaten Gianyar. E-Jurnal EP Unud, 6(1);

Susilowati,dkk.(2020). Peran Perempuan Pengrajin Bambu Dalam Meningkatkan Pendapatan Keluarga Di Desa Loyok Kecamatan Sikur Kabupaten Lombok Timur. Jurnal Pendidikan Ekonomi dan Kewirausahaan, 4(1): 95-103

Tambunan, Tulus T.H. Ghalia Indonesia.2003. Perekonomian Indonesia : Beberapa Masalah Penting. Jakarta.

Todaro, Michael P. Erlangga.1998. Pembangunan Ekonomi di Dunia Ketiga. Jakarta. 